上田幸介・川上寿昭

Deconvolution analysis 法を用いた動態解析の精度 と再現性を確かめるために流量や摂取率を自由に変える ことのできる動態解析用モデルを試作し, 出力部の平均 通過時間 - 攝取率 - 入力部と出力部の流量比を求め, 投 与量とサンプリング間隔が結果におよぼす影響について 検討した。

今回の実験において解析結果に与える影響がカウント 数よりもサンプリング間隔の方が大きかったのは，カウ ント数に応じたスムージング処理を行ったためであり， 解析結果の精度と再現性を良くするためにはカウント数 を犠牲にしてもデー夕採取間隔を短くする必要があると 考えられた。

\section{1．左心室自動輪郭抽出による心駆出率測定に関する 検討（技術的検討）}

日立メディコ柏工場システム設計部

○北川崇二

大阪大学医学部附属病院中央放射線部 RI 検查室 中村幸夫・久住佳三

マルチゲート心プールイメージから左心機能パラメー 夕を得るためには, ROI の設定が不可避であり手操作が 介在することから, 結果の再現性や精度が問題となって いる、今回われわれは ROI 設定を自動化することにより 左室駆出率などの測定を完全自動化し, この問題の解決 をはかった。

自動認識した ROIを用いて算出した $\mathrm{EF}$ と熟練者に よるマニュアル ROIを用いて算出した EFを比較した 結果, 安静時データ107例処理中, 認識成功96例, 成功率 $89.7 \%$ の成績であり，相関係数 $0.94(\mathrm{y}=1.02 \mathrm{x}+1.6)$ の 有意な正相関を得た。

\section{2. 左心室自動輪郭抽出法を用いた心機能パラメータ の検討}

東京女子医大病院放射線科

○一和田雅義・亀卦川孝司・栗原慎一郎 金谷信一・金谷和子・臼倉政雄 倉上光市・南 忠男

心電図同期型心プールイメージから左心室輪郭を完全 自動的に抽出する方法は, 精度, 再現性の向上に有用で ある、そこで，ペースメーカ植え込み患者を対象として 収集時間の異なる種々の $\mathrm{S} / \mathrm{N}$ 比を持つイメージに対し 種々の遮断周波数を有するバターワース・フィルタを適 用し抽出された左心室輪郭と, 算出された EF, PER, PFRを検討した。

〔結果〕100心拍加算画像に対して，0.09〜0.18，150
心拍加算には0.09〜0.21，200心拍加算には0.09〜0.21， 300 心拍加算には0.09〜0.24，500心拍加算には $0.09 \sim 0.30$ Cycle $/$ pixel が適当と考えられ，算出された 心機能パラメー夕に有意差は認められなかった。

\section{座長集約}

このセッションは心プールシンチグラフィのコンピュ 一夕解析に関するものである. 最近は心機能評価も従来 のマニュアルによるスレッショルド法から自動解析法に よる精度が検討されるようになってきた．演題 $547 ， 551$ ， 552 は左心室の自動輪郭抽出であり, 演題548, 549 は factor analysisであり，550席は動態解析モデルによる解析 である。

左心室の自動輪郭抽出のプログラムはコンピュータ・ メ一力各社が病院と共同開発を行い一応の基準に達して いるようであるが，その処理もそ机ぞれ特徴があり，ま だまだ改良の余地が残されているようである。前処理で 547，551席は画質のノイズ成分の除去のために，デジ夕 ル・バンドパス・フィルタを用い認識率の向上をはかっ て扔り，552席は遮断周波数を変えたバターワース・フィ ル夕を適用し加算心拍数との関係をみている.547席は臨 床での心駆出率（EF）の測定精度が連続の無作為抽出で 左室造影法やマニュアルのマルチゲート法を非常によく

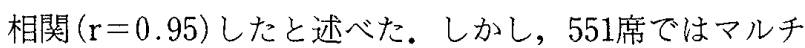
ゲート像の左室概略範囲の time activity curveから拡 張末期 (ED) 像と収縮末期 (ES) 像の 2 フレームだけを 抽出，処理することにより処理時間が $2 \sim 3$ 分に短縮で きる所に特徴があると言われた。まだ，いろんな症例に ついて証明されておらず不安が残る点である。全てのフ レームの処理から求めると15～16分かかるらしい. 佐藤 氏（日本大学板橋病院）は，(1)バンドパスフィルタの次 数を 6 次にすることと, (2) 2 次微分の変曲点間を $7: 3$ に配分して左室輪郭認識のエッジとしたカットオフ値の 意義について質問があった.551席の北川氏は(1)について は高次数にする程，フィル夕の空間周波特性の肩のスロ ープはシャープになるが，認識率に余り影響しないので 6 次位が適当である。 8 次までできるが 6 次は 7 秒， 8 次で11秒かかり，全フレームについて計算するときはこ の数秒の時間が大きく影響するので 6 次でおさえた。(2) については $7 ： 3$ というのは実験的に得た值であって， このカットオフ值が 5 ：5や $6: 4$ でも余り影響ないが 認識の成功率を示すことになると答えた.552席は前処理 として遮断周波数を有するバターワース・フィルタを適 用していて，マルチゲートの心拍加算が $100 〜 5000$ 間で 周波数を適当な值にすると心機能パラメー夕に有意差を 